This item was submitted to Loughborough's Research Repository by the author.

Items in Figshare are protected by copyright, with all rights reserved, unless otherwise indicated.

\title{
A new horizon in European sports law: The application of the EU state aid rules meets the specific nature of sport
}

PLEASE CITE THE PUBLISHED VERSION

http://dx.doi.org/10.1080/17441056.2017.1311146

\section{PUBLISHER}

(c) Taylor \& Francis

\section{VERSION}

AM (Accepted Manuscript)

\section{PUBLISHER STATEMENT}

This work is made available according to the conditions of the Creative Commons Attribution-NonCommercialNoDerivatives 4.0 International (CC BY-NC-ND 4.0) licence. Full details of this licence are available at: https://creativecommons.org/licenses/by-nc-nd/4.0/

\section{LICENCE}

CC BY-NC-ND 4.0

\section{REPOSITORY RECORD}

Garcia, Borja, An Vermeersch, and Stephen Weatherill. 2019. "A New Horizon in European Sports Law: The Application of the EU State Aid Rules Meets the Specific Nature of Sport". figshare. https://hdl.handle.net/2134/24752. 


\title{
A new horizon in European sports law: The application of the EU state aid rules meets the specific nature of sport
}

Borja García (Corresponding author): School of Sport, Exercise and Health Sciences; Loughborough University, UK. b.garcia-garcia@lboro.ac.uk @DrBorjaGarcia

An Vermeersch: Faculty of Law; Department of Criminology, Criminal Law and Social Law; Ghent University, Belgium.

Stephen Weatherill: Somerville College, Oxford University, UK.

\begin{abstract}
A recent influx of cases on state aid granted to sport undertakings in several EU Member States has brought to the fore the debate on the interpretation and application of this particular competition policy provision to the sports sector. This article reviews the recent Commission decisions on state aid in order to discuss the extent to which a coherent approach by the Commission can be found. The article notes the Commission's readiness to treat support for sports infrastructure as an aspect of 'State responsibility', which tends to generate a positive assessment under EU state aid law and contrasts this with its critical scrutiny of financial support granted to ailing sports clubs, where the Commission has been more cautious. It also discusses the wider political and policy implications of the application of European state aid rules to sport. Its core inquiry is how convincing is the case that sport deserves to be treated as a special case, distinct from other areas of economic activity?
\end{abstract}

Keywords: European Union competition law; Application of state aid to sport; European Commission; football

(C) Borja García, An Vermeersch and Stephen Weatherill 2017

Published in European Competition Journal.

Cite as: García, B., Vermeersch, A. and Weatherill, S. (2017) 'A new horizon in European sports law: The application of the EU state aid rules meets the specific nature of sport', European Competition Journal, DOI: http://dx.doi.org/10.1080/17441056.2017.1311146. 


\section{Introduction}

The ruling of the Court of Justice in Walrave ${ }^{1}$ initiated the development of European sports law. Much of the early attention was devoted to the application of the free movement provisions, especially following the landmark Bosman case ${ }^{2}$ and others such as Lehtonen ${ }^{3}$ and Deliège. ${ }^{4}$ This trend was accompanied by examination of the application of competition policy provisions to sport once the Court of Justice finally tackled this issue in Meca-Medina. ${ }^{5}$ This ruling explained the Court's view that that all regulations of sporting organisations which exert economic effects are subject to review and that their legality under competition law can be decided only on a case by case basis. ${ }^{6}$ This is now to be read in the light of the introduction into the Treaty with effect from 2009 of Article 165 TFEU, which directs that the Union shall take into account the "specific nature" of sport, although this seems more confirmation of the Court's

\footnotetext{
${ }^{1}$ Case C-36/74, Walrave and Koch v. Association Union Cycliste Internationale, ECLI:EU:C:1974:140.

2 Case C-415/93, Jean Marc Bosman v. Union Royale Belge Sociétés de Football Association, ECLI:EU:C:1995:463.
}

${ }^{3}$ Case C-176/96, Jiry Lehtonen and Castors Canada Dry Namur-Braine v. Féderation Royale Belge des Sociétés de Basketball ASBL (FRBSB), ECLI:EU:C:2000:201.

${ }^{4}$ Joined Cases C-51/96 and C-191/97, Christelle Deliège v Ligue Francophone de Judo et Disciplines Associées ASBL, ECLI:EU:C:2000:199.

${ }^{5}$ Case C-519/04 P, David Meca-Medina and Igor Majcen v. Commission of the European Communities, ECLI:EU:C:2006:492.

${ }^{6}$ See for example Stephen Weatherill, 'Anti-doping revisited - the demise of the rule of 'purely sporting interest'?’ (2006) 27 ECLR 645. 
approach than reformation. ${ }^{7}$ However, these developments mostly concerned cases where internal rules and regulations of sports governing bodies were challenged as an anticompetitive practice or as an abuse of dominant position. The rulings confirm that EU competition law is indeed applicable to sport, but the interpretation of the law has focused on the application of Articles 101 and 102 TFEU to what are in form private practices.

There is a public dimension to European sports law which has so far remained mostly hidden as a result of a lack of cases to adjudicate. This concerns the legality of state aid granted to the sports sector, which is subject to control pursuant to Articles 107-109 TFEU. Given the relatively high number of sport-related legal cases during the last two decades it is perhaps surprising to see that state aid has been minimally involved until very recently. This is even more striking if one considers the strategic importance of sport for the public sector in Europe. ${ }^{8}$ In many countries generous subsidies are treated as essential parts of national, regional or local sport policies. ${ }^{9}$

The last five years, however, have seen an increase in the number of cases involving state aid and sport. We have documented a total of 21 cases, with different outcomes. Since 2011, the Commission has taken a positive decision in 15 sports cases and has

\footnotetext{
${ }^{7}$ As the Court itself confirms in Case C-325/08, Olympique Lyonnais $v$ Olivier Bernard, ECLI:EU:C:2010:153.

${ }^{8}$ Houlihan, 'Public sector sport policy: Developing a framework for analysis' (2005) 40 International Review for the Sociology of Sport 163.

${ }^{9}$ Houlihan and Green (eds.) Comparative Elite Sport Development: Systems, Structures and Public Policy, (Butterworth-Heinemann 2008).
} 
decided that the measures were compatible with the internal market, but there have been also cases in which state aid was found incompatible with EU law. Broadly, the cases fall into two groups: those involving support for sports infrastructure, where the Commission has commonly, but not inevitably, found the aid to be compatible with the internal market, and those involving financial aid for sports clubs, where the Commission has been noticeably more cautious when invited to find in favour of the arrangements' compatibility with EU state aid law. And whereas the state aid rules are potentially relevant to all sports, most of the recent dossiers relate to football. Indeed, the latest state aid sport-related cases adjudicated by the Commission as recently as July 2016 were completely focused on football and concerned some of Europe's top professional clubs. Four Dutch football clubs (NEC Nijmegen, MVV Maastricht, Willem II, Den Bosch) were found to have received aid provided by local municipalities in the Netherlands which was compatible with EU law, while one (PSV Eindhoven) was found to have received no aid at all. ${ }^{10}$ On the other hand, the Spanish state has been asked to recover incompatible state aid given to seven professional football clubs (Real Madrid, F.C. Barcelona, Athletic Club Bilbao, C.A. Osasuna, Valencia C.F., Elche C.F. and Hércules C.F.). ${ }^{11}$

The article will now proceed in three steps. First, the general framework for the application of the state aid rules will be outlined, including reference to the Treaty

\footnotetext{
${ }^{10}$ Commission, 'State aid: Commission clears support measures for certain football clubs in the Netherlands’ (Press release) IP-16-2402, 4 July 2016.

${ }^{11}$ Commission, 'State aid: Commission decides Spanish professional football clubs have to pay back incompatible aid’ (Press release) IP-16-2401, 4 July 2016.
} 
direction that the "specific nature" of sport shall be taken into account. Second, the most recent cases of aid in the sports sector will be analysed: we separate our analysis dealing first with the cases concerning infrastructure and, second, those related to subsidies and concessions made to clubs. Finally, the legal and political consequences will be discussed. At the heart of the inquiry lies the question of the extent to which the acceptance in the Court's landmark rulings in Walrave, ${ }^{12}$ Bosman $^{13}$ and Meca-Medina ${ }^{14}$ that sport is special (though not quite as special as sports governing bodies typically claim) may be and should be transplanted from the private dimension of European sports law to influence also the supervision of public authorities granting aid. The question is whether an integrated law of sport in the EU's internal market, spanning both private practices and public support and respectful of Article 165 TFEU's direction to take account of the specific nature of sport, is emerging.

2. State aid and sport: The application of Articles 107-109 and the influence of Article 165 TFEU

Articles 107-109 TFEU contain the EU's system for supervising subsidies and aid granted by public authorities in the Member States. The provisions are structurally straightforward. A basic prohibition against aid contained in Article 107(1) is accompanied by two exceptions, the first a narrow range of aids that according to

\footnotetext{
${ }^{12}$ Case C-36/74 (n 1).

${ }^{13}$ Case C-415/93 (n 2).

${ }^{14}$ Case C-519/04 (n 5).
} 
Article 107(2) are automatically permitted and the second a more generous, though still tightly controlled, admission in Article 107(3) that some aid may be treated as lawful.

Article 108 makes clear that the Commission is the institution charged with the responsibility of deciding whether or not an aid may benefit from the possibility of exoneration from prohibition pursuant to Article 107(3). This is facilitated by the obligation imposed by Article 108(3) to notify the Commission of plans to grant new aid, accompanied by an obligation not to put proposed measures into effect pending Commission investigation. Violation of these procedural obligations renders the aid unlawful, which means that an application may be pursued by an interested third party before a national court to force its repayment. ${ }^{15}$ The Commission by contrast must assess whether aid is compatible with the internal market even if it has not been notified. However, although it is not unknown for unnotified aid to receive a green light from the Commission, ${ }^{16}$ this is relatively uncommon. Non- notification is typically rooted in the the grantor's wish to hide the aid's very existence, and consequently it is highly unlikely to secure approval. In order to wipe out the competitive distortion it has caused in the market, aid which is not compatible with the internal market must be recovered by the Member State.

This system grants the Commission a strategically important supervisory role. Article 109 grants the Council a general competence to adopt Regulations to facilitate the

\footnotetext{
${ }^{15}$ Reg. 2015/1589, (2015) OJ 248/9; see also Commission Notice on the Enforcement of State aid law by national courts, (2009) OJ C85/1.

${ }^{16}$ There are examples among the cases on sport: e.g. Case COMP/ SA.35501, France Euro 2016, Case COMP/ SA.40168 Willem II.
} 
application of Articles 107 and 108 but the Council and Parliament are largely kept out of detailed decision-making. Article 108 allows the Council exceptionally to deem aid to be compatible with the internal market, which subverts the Commission's primacy, but not least since Council action must be unanimous, it has in fact been little used. ${ }^{17}$ The Court has gone out of its way to describe this provision as 'clearly exceptional in character'. ${ }^{18}$ Article 107(3)(e) allows the Council, on a proposal from the Commission, to add other categories of aid to the 'may be compatible' list. This is no dead letter - it was, for example, the basis of a Decision on aid to facilitate the closure of uncompetitive coal mines ${ }^{19}$ - but its use has been infrequent. In fact, the aid rules are perfect examples of a broader understanding of the EU as a site for mutual hand-tying backed by credible systems of enforcement, and of the Commission as the necessarily autonomous decision-maker in whose (appearance of) impartial judgement all parties choose in common to place their faith. It means too that the Commission enjoys a rather wide discretion.

In its assessment of state aid cases, the Commission traditionally follows the two- step approach that is mapped out by Article 107. First, the Commission assesses whether the measure at stake qualifies as state aid; then, if it does qualify, it proceeds to determine whether it should be treated as compatible with the internal market or not.

\footnotetext{
${ }^{17}$ See Faull and Nikpay, The EU Law of Competition, $3^{\text {rd }}$ ed. (OUP 2014) 329-337; Quigley, EU State Aid Law and Policy, $3^{\text {rd }}$ ed. (Hart 2015) 497-499.

${ }^{18}$ Case C-110/02, Commission v Council, ECLI:EU:C:2004:395 [31]. There was bite as well as bark: in the case the Court annulled Council Decision 2002/114 authorising Portugal to grant aid to pig farmers.

${ }^{19}$ Council Decision 2010/787, (2010) OJ L336/24.
} 
According to Article 107(1) TFEU, “any aid granted by a Member State or through State resources in any form whatsoever which distorts or threatens to distort competition by favouring certain undertakings or the production of certain goods shall, in so far as it affects trade between Member States, be incompatible with the internal market”.

The plentiful case law of the Court has elucidated what is at stake in this definition, and in 2016 the Commission published a helpful Notice on the notion of a State aid. ${ }^{20}$ It follows that in order for a measure to qualify as state aid, the following four cumulative conditions have to be met:

1) The measure has to be granted out of or through State resources.

It is long established that the notion of aid should be interpreted with reference to the effect of a measure, not its form or its aim. ${ }^{21}$ The most common form of awarding state aid is by means of direct grants. In sports cases, the (co)funding of the construction and renovation of an infrastructure by the State is a key example. ${ }^{22}$ However, the notion of aid may readily catch exemption from taxes or social security or any kind of beneficial

\footnotetext{
${ }^{20}$ (2016) OJ C262/1.

${ }^{21}$ E.g. Case 173/73, Commission v Italy ECLI:EU:C:1974:71; Case C-241/94 France v Commission ECLI:EU:C:1996:353; Case C-276/02 Spain v Commission ECLI:EU:C:2004:521. See also Quigley (n 17), chapters 1.1 and 1.2 .

${ }^{22}$ See for example Commission Decision of 18 December 2013, Case COMP/ SA.35501, France EURO 2016; Commision Decision of 2 May 2013, Case COMP/ SA.33618, Sweden - Upsala arena.
} 
fiscal treatment, ${ }^{23}$ which is increasingly important in sport cases as we discuss further below. The aid must be imputable to the State. The term "State" encompasses public authorities at all levels: national/federal, regional, and local. ${ }^{24}$

2) The beneficiary of the measure must be an undertaking.

The term "undertaking" is defined broadly and includes "every entity engaged in an economic activity, regardless of the legal status of the entity and the way in which it is financed”. ${ }^{25}$ Sports clubs shall be considered undertakings to the extent they carry out economic activities such as selling broadcasting rights or concluding sponsoring or advertising agreements. ${ }^{26}$ Sports associations shall be considered undertakings if they themselves carry out economic activities such as the commercial exploitation of a sports event. $^{27}$

3) The measure must confer an economic advantage on the beneficiary undertaking which distorts or threatens to distort competition.

\footnotetext{
${ }^{23}$ Commission, 'Commission asks Italy to change its rules on accounting by profesional sports clubs ('Salva calcio’)’ (Press release) IP/04/854, 7 July 2004. Commission, ‘Commission closes case against Italy on accounting rules for profesional sports clubs ('Salva calcio’)’ (Press release) IP/05/1271, 13 October 2005.

${ }^{24}$ Quigley (n 17), Chapter 1.3.

${ }^{25}$ Case 41/90, Klaus Höfner and Fritz Elser v. Macroton GmbH, ECLI:EU:C:1991:161 [21].

${ }^{26}$ See for example Case C-519/04, Meca-Medina (n 5)

${ }^{27}$ See for example Case COMP/ AT.37398 Joint selling of commercial rights of the UEFA Champions League, (2003) OJ L 291/25.
} 
For these purposes an economic advantage is one which the undertaking could not have obtained under normal market conditions. Put another way, a public authority which is behaving like a private investor is not granting aid. This is commonly referred to as the 'market economy operator' test. Simple in principle, it is demanding to apply in practice, given the awkward and frequently hypothetical comparisons that are required. ${ }^{28}$ In the case of sports infrastructure, the intervention of the State may alter existing market conditions as a number of new/renovated infrastructures become available that allow the operators and the users of the infrastructure to benefit from facilities that would not be available on market terms. ${ }^{29}$

Use of this test led the Commission to decide not to intervene where the city authorities of Rotterdam had invested in the Ahoy complex, comprising the Sports Palace, other exhibition halls, and a congress centre. ${ }^{30}$ In this case the Commission concluded there was no conferral of economic advantage beyond normal market conditions. ${ }^{31}$ The terms of the deal were in line with the normal operation of the market. Thus it fell outwith the material scope of the state aid rules.

\footnotetext{
28 See more on how this principle has been applied in sports cases in section 3.2. below.

${ }^{29}$ See for example Commission Decision of 9 November 2011, Case COMP/ SA.31722, Hungary Supporting the Hungarian sport sector via tax benefit scheme, point 80; Commission Decision of 20 November 2013, Case COMP/ SA.37109, Belgium - Football stadiums in Flanders, point 25; Commission Decision of 18 December 2013, Case COMP/ SA.35501, France - EURO 2016, point 262. 30 Commission Decision of 21 October 2008, Decision 2009/713, The Netherlands - Investment by the municipality of Rotterdam in the Ahoy complex, (2009) OJ L 248/28.

${ }^{31}$ A challenge to this Decision was treated as inadmissible in Case T-90/09 Mojo Concerts BV et Amsterdam Music Dome Exploitatie BV v Commission, ECLI:EU:T:2012:30.
} 
The test also applies to financial support granted to clubs. The Dutch decisions of 2016 are separable into two groups: that concerning PSV Eindhoven, where the Commission's analysis persuaded it that a private investor would have behaved in a similar manner and where accordingly there was no aid, and the other four decisions where the examination revealed that aid had been granted, and so an inquiry into its compatibility with the internal market was conducted. ${ }^{32}$

As part of this criterion the measure must favour particular undertakings. This is commonly referred to as the requirement that the measure be selective in order to fall within the scope of Article 107. A measure of general application to all relevant undertakings in a Member State escapes the supervision asserted by State aid law. ${ }^{33}$ This condition is fulfilled when only a limited number of sports or only a limited number of clubs benefit from a measure. In the case of infrastructure, selectivity is particularly evident where the construction or renovation of infrastructure qualifies as “dedicated infrastructure” for one or a few beneficiaries. ${ }^{34}$ Where financial support is directed at individual clubs, the requirement is readily satisfied.

4) The measure has to affect intra-EU trade.

\footnotetext{
${ }^{32}$ Section 3.2.1 below.

${ }^{33}$ Quigley (n 17) chapters 1.4 and 1.5.

${ }^{34}$ Commission Decision of 9 November 2011, Case COMP/ SA.317220, Hungary - Supporting the Hungarian sport sector via tax benefit scheme, point 77.
} 
Since competitions between professional sports clubs have a clear international dimension and many tournaments have a European or worldwide dimension, the measures normally easily meet the required element of exerting an effect on intra-EU trade. ${ }^{35}$ Given the transnational character of not only football competitions but also the transfer market and markets for broadcasting, sponsorship and merchandise there is no difficulty in finding the required inter-State dimension even where relatively small clubs are in receipt of aid. ${ }^{36}$

The Block Exemption on de minimis aid might on occasion help to shelter aid from scrutiny. ${ }^{37}$ Its Article 3(2) contains the basic rule, supported by sector-specific adornment. The total amount of de minimis aid granted per Member State to a single undertaking shall not exceed $€ 200,000$ over any period of three fiscal years. Crossing that threshold triggers an obligation to notify the aid to the Commission.

If there is aid according to these four criteria discussed above, the matter turns to the second stage: the assessment conducted by the Commission into whether the aid is compatible with the internal market. So far, all positive Commission decisions in the

\footnotetext{
${ }^{35}$ See for example Commission Decision of 9 November 2011, Case COMP/ SA.317220, Hungary Supporting the Hungarian sport sector via tax benefit scheme, point 81; Commission Decision of 20 November 2013, Case COMP/ SA.37109, Belgium - Football stadiums in Flanders, point 26; Commission Decision of 18 December 2013, Case COMP/ SA.35501, France - EURO 2016, point 263.

${ }^{36}$ E.g. Case COMP/ SA.40168 Willem II, esp. paras. 15, 39-40; Case COMP/ SA.41614 Den Bosch, paras. $7,62-63$.

${ }^{37}$ Regulation 1407/2013 of 18 December 2013 on the application of Articles 107 and 108 of the Treaty on the Functioning of the European Union to de minimis aid (2013) OJ L352/1.
} 
recent sports cases were assessed on the basis of Article 107(3)(c) TFEU which states that that: "Aid to facilitate the development of certain economic activities or of certain economic areas, where such aid does not adversely affect trading conditions to an extent contrary to the common interest" may be considered to be compatible with the common market. $^{38}$

In order to assess whether a measure is compatible under Article 107(3)(c) TFEU, the Commission balances positive and negative effects of the aid. ${ }^{39}$ In applying the balancing test, the Commission assesses whether the state aid pursues a policy objective of common interest, is necessary and appropriate and does not cause undue distortion of competition. In cases involving support for clubs in financial difficulty the focus is on the Commission's Guidelines on aid for rescue and restructuring, which constitute a concrete application of the 'gateway' found in Article 107(3)(c). ${ }^{40}$ Of particular significance to aid for infrastructure today is Regulation 651/2014, which is the Block

\footnotetext{
${ }^{38}$ Other paragraphs of Article 107(3) might in future become relevant. Aid 'to promote the economic development of areas where the standard of living is abnormally low or where there is serious underemployment' might fit sport as a tool of regional policy; aid 'to promote the execution of an important project of common European interest' might touch sport; and also included on the list is 'aid to promote culture and heritage conservation where such aid does not affect trading conditions and competition in the Union to an extent that is contrary to the common interest', which might at a stretch, and supported by reference to Article 167(4) TFEU, apply to some aspects of sporting activity.

${ }^{39}$ See for example Commission Decision of 9 November 2011, Case COMP/ SA.31722, Hungary Supporting the Hungarian sport sector via tax benefit scheme, point 85; Commission Decision of 20 November 2013, Case COMP/ SA.37109, Belgium - Football stadiums in Flanders, point 29.

${ }^{40}$ Guidelines on State aid for rescuing and restructuring non-financial undertakings in difficulty
} (2014) OJ 2014, C249/01. 
Exemption Regulation applicable to state aid. ${ }^{41}$ This document, which contains 59 Articles and three Annexes and stretches over 78 pages of the Official Journal, sets out at great length the criteria that determine whether particular forms of aid are to be treated as compatible with the internal market. Its Article 55 addresses "aid for sport and multifunctional recreational infrastructures" and provides that such aid is to be treated as compatible with the internal market within the meaning of Article 107(3) TFEU and so is exempted from the notification requirement of Article 108(3) TFEU provided that the conditions set out in the Regulation are met.

Regulation 651/2014's predecessor did not mention sport at all, so this is a watershed which suggests a need for separate treatment of Commission practice before the entry into force of the Regulation and practice afterwards, beginning in July 2014. This article respects this pattern, but equally it cautions that the Regulation is not transformative. It is essentially a codification of Commission practice; its concern is only for infrastructure projects, not wider matters that arise in cases of aid granted in the sports sector such as aid to ailing clubs, and, most of all, it offers no serious engagement with the intellectual heart of this subject, which is the impact of Article 165 TFEU. Regulation 651/2014 pays mere lip service to Article 165, confining it to a passing reference in the Preamble. ${ }^{42}$ The important point is that, besides the block exemption, the Commission has begun to make use also of Article 165 TFEU in order to shape its treatment of sport as an economic activity subject to the Treaties. The potential

\footnotetext{
${ }^{41}$ Commission Regulation 651/2014 of 17 June 2014 declaring certain categories of aid compatible with the internal market in application of Articles 107 and 108 of the Treaty (2014) OJ, L187/1

${ }^{42}$ Ibid. recital 74.
} 
significance of this is high. Free movement law had its Bosman, ${ }^{43}$ competition law its Meca-Medina. ${ }^{44}$ State aid awaits the landmark judgment that will elucidate how far EU law is to be adapted to pay due respect to the claim that sport is special. Even though Article 165 TFEU is not formally horizontal in nature, the Court was in the past willing to absorb the non-binding Amsterdam Declaration on Sport in applying internal market law ${ }^{45}$ so there is no likelihood of it taking any lesser view of Article 165, which is binding. Olympique Lyonnais v Olivier Bernard, in which the Court ruled that the legal assessment of the transfer system as a restriction on free movement shall embrace "the specific characteristics of sport in general, and football in particular, and of their social and educational function” provides ample confirmation. ${ }^{46}$ The Court there added that "the relevance of those factors is also corroborated by their being mentioned in the second subparagraph of Article 165(1) TFEU”. ${ }^{47}$

So state aid law is constitutionally connected to Article 165's commitment to the "specific nature of sport". The key question is what this, in fact, means in concrete terms for analysis of state aid in the context of sport. The European Commission's 2007 White Paper on Sport makes no mention at all of state aid. ${ }^{48}$ The supporting and much longer Staff Working Document contains a brief comment on state aid rules. ${ }^{49}$ The

\footnotetext{
${ }^{43}$ Case C-415/93, Bosman (n 2) [106].

${ }^{44}$ Case C-519/04 P Meca-Medina (n 5), especially [42-45].

45 Cases C-51/96 \& 191/97 Deliège (n 4), [41-42]; Case C-176/96 Lehtonen (n 3) [32-33].

${ }^{46}$ Case C-325/08, Bernard (n 7) [40].

47 Ibid.

${ }^{48}$ Commission 'White Paper on Sport’ COM (2007) 391, 11 July 2007.

${ }^{49}$ Commission, 'The EU and Sport: Background and Context - Accompanying document to the White Paper on Sport' SEC (2007) 935, para. 3.2.2.
} 
comment begins with the observation that "there are very few decisions so far" where the Commission has applied the Treaty rules to sport. According to the Commission staff document, public support measures in sport generally finance either infrastructure or activities of individual sports clubs.

The document states that public financing related to the construction of sports infrastructure can be considered not to constitute state aid, provided that certain conditions are fulfilled. To clarify this general statement, the document makes reference to a letter from the European Commission's Directorate-General for Competition to Germany regarding State funding for the Hannover football stadium. ${ }^{50}$ This case dates back to the year 2000 when the organization of the 2006 FIFA World Cup was assigned to Germany. Where (1) the type of infrastructure involved is generally unlikely to be provided by the market because it is not economically viable; (2) it is not apt selectively to favour a specific undertaking; and (3) where it is a facility needed to provide a service that is considered as being part of the typical responsibility of the public authority to the general public, the matter will escape the EU's state aid rules. The elaboration of the Commission's practice in cases involving infrastructure, and the adoption of sports-specific treatment of aid for infrastructure in Article 55 of Regulation $651 / 2014$, is the subject of dedicated examination further below.

In relation to public subsidies to individual clubs, the Commission's 2007 staff working document concluded rather brusquely that although amateur clubs are generally not considered as undertakings within the meaning of EU state aid law, with the consequence that subsidies granted to such clubs are generally not covered by the State aid rules, by contrast professional sports clubs are engaged in economic activities, and 
so there is no compelling argument why they should be exempted from the State aid rules. In fact, the document went further and stated that:

The need to ensure competitive equality between players, clubs and competitions as well as the necessity to ensure uncertainty of results can in fact be guaranteed most effectively by the application of State aid rules, which are meant to establish a level playing field and ensure that States or municipalities that are most willing or able to grant subsidies to their clubs will not disrupt fair competition. ${ }^{51}$

This far-sighted observation has a sharp bite when one comes to consider the July 2016 decisions concerning Spain's leading football clubs. This matter too is examined more fully below in section 3.2.2 of this article.

The European Commission's 2011 Communication on Sport touches upon the topic of state aid even more briefly. ${ }^{52}$ After a few general lines, it simply repeats that there have only been a few decisions concerning State aid to sport. As a concluding statement, it is mentioned that "as in other sectors in a similar situation, stakeholders have repeatedly called for further clarification regarding the financing of infrastructure and sport organisations”. 53

\footnotetext{
${ }^{51}$ Ibid, para. 3.2.2.

${ }^{52}$ Commission, 'Communication from the Commission to the European Parliament, the Council, the European Econmomic and Social Committee and the Committee of the Regions on developing the European dimension of sport’ COM (2011) 12 final, 18 January 2011.

${ }^{53}$ Ibid, para. 3.3.
} 
While reference to some sport-related cases has been made already, we move to discuss the most recent decisions of the Commission in the application of state aid rules to sport. It will be evident that at least some recognition of the special character of sport is emerging. This reveals that, as has already occurred in connection with EU free movement and competition law, the application of state aid law too requires a degree of sensitivity to the special nature of sport, as foreseen by Article 165 TFEU.

\section{Analysis of recent Commission decisions: In search of the specificity of sport under state aid law}

There has been a clear surge in sport-related state aid cases over the last few years. A total of 21 European Commission decisions have been identified since 2011. One can identify two groups of activities that are being targeted for investigation as potentially illegal state aid. On the one hand, there are those instances in which public authorities (mostly local and/or regional) participate in the construction or refurbishment of sports venues. On the other hand, there are cases where sports clubs are directly helped by the authorities through tax/debt relief schemes, financial backing, real estate operations, or a combination of these. The analysis that follows respects this twofold division.

\subsection{State aid and sports infrastructure}

The large number of cases linked to the building or renovation of sporting venues with positive decisions (a selection of which is analysed below) demonstrate that the European Commission considers the state measures (if criteria are met) are compatible 
with Article 107(3) TFEU in that area. This was already evident in the case of the Hannover football stadium that we analysed previously in the article, and where the Commission sent a letter to Germany explaining under which conditions aid for building stadiums may be permited. ${ }^{54}$ This thinking of the Commission paved the way to the adoption of sport-specific treatment of aid for sport and multifunctional recreational infrastructure in Article 55 of Regulation 651/2014, the Block Exemption Regulation. $^{55}$

Regulation 651/2014 replaced Regulation 800/2008, the previously applicable Block Exemption, which did not refer to sport at all. So this created new regulatory terrain. Article 1(1)(k) brings "aid for sport and multifunctional recreational infrastructures" within the Block Exemption Regulation's scope. What is at stake here is the circumstances in which public authorities may subsidise the construction or operation of a facility that will be used by a professional sports club. Article 55 provides a careful explanation of what room for manoeuvre is permitted to public authorities. The key features, each granted detailed treatment in the twelve intricate paragraphs of Article 55, are that there shall not be a single professional sport user; ${ }^{56}$ and that access, pricing and

\footnotetext{
${ }^{54}$ See also Gerlinger, 'Stadiums for FIFA World Cup Germany 2006 and European law on State aid: A case of Infrastructure measures?’ (2003) 3 International Sports Law Journal 9.

${ }^{55}$ Commission Regulation (EU) 651/2014 of 17 June 2014 declaring certain categories of aid compatible with the internal market in application of Articles 107 and 108 of the Treaty, (2014) OJ L187/1.

56 The regulation's definition section, Art 2(143), provides that professional sport "means the practice of sport in the nature of gainful employment or remunerated service, irrespective of whether or not a formal labour contract has been established between the professional sportsperson and the relevant sport organisation, where the compensation exceeds the cost of participation and constitutes a significant part
} 
usage shall proceed on a transparent and non-discriminatory basis; and that the amount of aid shall be strictly controlled according to rules that govern the permitted relationship between eligible costs and operating profit and loss.

Article 4(bb) withdraws the exemption from investment aid for sports and multifunctional infrastructures which exceeds $€ 15$ million or the total costs exceeding $€$ 50 million per project and from operating aid for sports infrastructure which exceeds $€ 2$ million per infrastructure per year. Article 4(2) adds that the thresholds shall not be circumvented by artificially splitting up the aid schemes or aid projects. Bigger projects need to secure an individual exemption and so need to be notified to the Commission.

The tension in the content of these exemptions is between the potential general value to the community of the availability of high-quality infrastructure on the one hand and, on the other, the normal and indeed commercially sensible pattern where one or two large sports clubs typically become the dominant user of sports arenas. As a general rule the closer the project conforms to the former pattern, the more likely that public funding in its support is to secure the approval of by the Commission. It would be possible to view this tension through the prism of Article 165 TFEU but, as mentioned above, Regulation 651/2014 is barren of concrete reliance on Article 165 TFEU. This is not true of the Commission's Decisions, though. In consequence the quest to gain insight into the beating intellectual heart of EU sports law it is necessary to look beyond the Regulation, the value of which is predominantly focused on practice and planning, and

of the income for the sportsperson. Travel and accommodation expenses to participate to the sport event shall not be considered as compensation for the purposes of this Regulation”. 
engage with the intricacies of the Commisison's individual decisions, and in particular their reliance on Article 165 TFEU.

Therefore the article turns now to discuss in more depth the significance of a selection of the most relevant cases in relation to sports infrastructure. We will deal, in turn, with the Commission decisions relating to football stadiums in Flanders, the new multisport arena in Copenhagen and the building of stadiums in France in preparation for the 2016 European Football championships (EURO 2016). An overall assessment is then provided.

\subsubsection{Football stadiums in Flanders}

The Commission decided to raise no objections in Football stadiums in Flanders. ${ }^{57}$ Belgium had notified the Commission of the Flemish government's plan to grant $€ 8$ million in aid to support the renovation and the construction of multifunctional football stadiums as part of a scheme to ensure that professional football in Flanders "generates a higher social return”, while also improving the quality of stadiums used for professional football. The Commission readily classified this as aid within the meaning of Article 107: it was granted exclusively from public funds; it conferred an economic advantage on owners and users of stadiums (and Commission noted that football clubs should be considered as “undertakings”); selectivity was present because the measure targeted only stadiums used by first and second league football clubs located in Flanders or Brussels; and distortion of competition flowed from that benefit that was made

\footnotetext{
57 Case COMP/ SA.37109, Belgium - Football stadiums in Flanders.
} 
available locally, which in turn affected inter-State trade because "competition between professional football clubs clearly has an international dimension”. ${ }^{58}$ In any event the measure was aimed at adapting stadiums to UEFA criteria for European football games.

The Commission therefore turned to assessment in the light of Article 107(3)(c) TFEU, which in sports cases is the most important of the gateways and which provides that "aid to facilitate the development of certain economic activities or of certain economic areas, where such aid does not adversely affect trading conditions to an extent contrary to the common interest may be treated as compatible with EU law”.

The Commission found, first, that the project of renovating stadiums "can be considered a State responsibility towards the general public" and in making this bold assertion, examined further below, it relied explicitly on the Amsterdam Declaration on Sport and on Article 165 TFEU, which, it noted, "both acknowledge the social significance of sport”. It lauded too sport's educational role, as well as its social, cultural and health dimension. The aim of the measure is "to realize multifunctional football stadiums in order to ensure that professional football in Flanders/Brussels Capital Region generates a higher social return, while at the same time improving the quality of stadiums used for professional football". ${ }^{59}$ It noted too the project's emphasis on multifunctional use of the football stadium in order to achieve broader societal goals: the stadium "should have an added value for society”. 60

\footnotetext{
${ }^{58}$ Ibid point 26.

${ }^{59}$ Ibid point 3.

${ }^{60}$ Ibid point 12.
} 
The aid was found to be well-targeted in the sense that it addresses a specific problem, that of under-investment in football infrastructure, and moreover support for upgrade was tied to establishing social return. In short: "Without jeopardising the primary football objective, the subsidised infrastructures should thus be opened to the general public. This will ensure that several different types of users and sectors should be able to benefit from the subsidized facilities”. ${ }^{61}$

Finally the Commission agreed that the distortion of competition and the effect on trade was limited. Promised transparency was approved as a means to enable third parties (including competitors) to verify whether the aid was justified and its conditions fulfilled. And the promise to set prices by benchmarking was approved as a means to prevent distortion of competition to the detriment of privately owned and funded facilities. ${ }^{62}$ Plainly this anxiety about the need for transparency has been eagerly carried over into the terms set by Article 55 of Block Exemption Regulation 651/2014, considered above.

\footnotetext{
${ }^{61}$ Ibid point 38.

62 Supervision of disparate pricing mechanisms is probably the most awkward and ad hoc issue arising in these several decsions: Craven, 'State aid and sports stadiums: EU sports policy or deference to professional football' (2014) E.C.L.R. 453.
} 


\subsubsection{Financing of a new multiarena in Copenhagen.}

The Commission proceeded to a formal approval of Financing of a new multiarena in Copenhagen. ${ }^{63}$ The city planned to co-fund the building of a multiarena offering facilities for music, culture and sport, seating up to 15,000 people. That the aid was granted through State resources was plain. It was in the view of the Commission at least plausible that a selective economic advantage would result at one or all of the relevant levels, namely construction, operation and/or use of the arena. Public co-financing of the multiarena was capable of distorting competition and having an effect on trade between Member States (especially between Denmark and Sweden, and potentially Germany too). The key question therefore focused on whether the aid could be treated as compatible with the internal market. The Commission took a favourable view. Article 107(3)(c) was once again the gateway. The Commission considered that the project would benefit the general public and that what was at stake "can be considered as a State responsibility, particularly in light of the Amsterdam Declaration on Sport and Article 165 of the Treaty”. ${ }^{64}$ The Commission also relied on Article 167(4): the arena would promote cultural diversity in the common interest. Moreover, the Commission, after examination of alternatives, was persuaded that the new facility would complement rather than compete with existing venues: it would lead to more events being staged. This was true not only of Danish venues but also those in Sweden, in particular that in Malmö, closely situated over the bridge from Copenhagen. The Commission also noted that private financing of the venture was demonstrably not forthcoming, and that the State's support was limited to bridging the gap between what

\footnotetext{
${ }^{63}$ Commission Decision of 15 May 2008, Case COMP/ SA.33728, Denmark - Multiarena Copenhagen.

${ }^{64}$ Ibid point 34.
} 
could be secured on the market and what was needed. And use of the multiarena would be pursued on a non-discriminatory basis with no "captive user".

\subsubsection{France 2016}

In December 2013 the Commission announced it would raise no objections to the plans to renovate football stadiums in France in preparation for the European Football championships to be held in that country in $2016 .{ }^{65}$ That the matter was notified was itself proof of the rising profile of EU state aid law applied to sport: the arrangements for supporting construction of stadia for the 2006 FIFA World Cup in Germany came to the attention of the Commission only after two complaints were lodged. ${ }^{66}$ The 2016 project, based on several different models of funding explained in detail in the documentation, had been notified to the Commission by the French authorities and covered the renovation and subsequent use of nine stadiums, in Bordeaux, Marseille, Lille, Nice, Saint-Etienne, Toulouse, Paris, Lens and Lyon. Only the stadium in Lyon is privately owned. After examination of the specific features of each of the nine arrangements, the Commission proceeded to find that there was state aid within the meaning of Article 107. Support through State resources was plainly present. An advantage was selectively conferred on particular undertakings, which would be able to provide services by using the stadiums. In some cases this would be achieved through a private company, in others by the public authority itself acting as an economic operator. Moreover each stadium, which was used only for the duration of a single month in the summer of 2016 for the tournament, is designed in the longer term to be used

\footnotetext{
${ }^{65}$ Commission Decision, Case COMP/ SA.35501.

${ }^{66}$ Craven (n 62).
} 
principally by a top-level French professional football club, the "captive user". The public authorities were not acting purely as would a private investor. The Commission also readily identified the necessary effect on competition and on trade between Member States. The stadiums would be used for major football and other cultural events that would be of international interest. The very plan was to compete with facilities in other Member States (and beyond) to secure the right to stage major events.

The question was whether the aid should be treated as compatible with the internal market. France relied on Article 107(3)(c) and the Commission agreed that the criteria were met. The project pursued a matter of common interest and was structured in a way that was necessary and proportionate to achieve its ends and did not cause any undue distortion of competition. The Commission referred to the support involved as capable of being considered as a State responsibility, and referred to both the Amsterdam Declaration on Sport and Article 165, as well as Article 167(4) on cultural diversity. It emphasised too the multifunctional virtues involved, stretching beyond the "captive user” football clubs. France could not aspire to such ambitious plans without this project -in particular the need to satisfy UEFA's stadium requirements is stressed by the Commission - and it would not be delivered by the private sector acting without State intervention. It would, in the view of the Commission complement, not replace existing different facilities. The Commission also stressed that compliance with EU public contracting rules and other applicable legal rules would limit the State support to that strictly required. It examined too and was satisfied by the structures for payment by the “captive user”, the clubs and other future users. 
The Commission's decision was limited to the aid needed for construction and renovation. As the conditions for the further commercial exploitation and use of the stadiums were not yet fully defined, France committed to notify the outstanding conditions of exploitation and use of the stadiums after the championship. France would also set up a control mechanism in order to guarantee market conditions for the use of resident clubs. ${ }^{67}$

\subsubsection{Overall assessment: a broadly favourable approach}

As explained above, Article 55 of Regulation 651/2014 has assumed a central role for future assessment of the compatibility with EU law of projects of this type, but its shape is heavily influenced by pre-existing Commission practice, especially the cases analysed above. Thus, they remain vividly helpful in showing the Commission's thinking. Moreover, any project that is unable to take advantage of the gateway that is Article 55 of the Block Exemption Regulation will need to be shaped with careful awareness of what the Commission has approved in the past. The Decisions in Flanders and France reveal a broadly comparable - and positive - assessment by the Commission. They follow a very similar reasoning, using almost the same arguments, to achieve the same results. A closely comparable approach was also taken in 2013, as plans to support the construction of multifunctional arenas in Erfurt, ${ }^{68} \mathrm{Jena},{ }^{69}$ and Chemnitz ${ }^{70}$ were found

\footnotetext{
${ }^{67}$ Commission, 'State aid: Commission approves French aid for construction and rennovation of stadiums for UEFA EURO 2016 Championship’ Press release IP/13/1288, 18 December 2013.

${ }^{68}$ Commission Decision of 20 March 2013, Case COMP/ SA.53135, Germany - Multifunktionsarena der Stadt Erfurt.
} 
compatible with the internal market pursuant to Article 107(3)(c). Swedish plans for a new arena in Uppsala were treated in the same way ${ }^{71}$ and so too were plans to renovate three stadia in Northern Ireland. ${ }^{72}$ Thus, a clear pattern is found here, which in turn offers a model for those engaged in planning such schemes in future.

A broader scheme in Hungary, involving granting tax concessions in order to induce undertakings to contribute to supporting training of young people, costs of personnel and creation or modernisation of sports infrastructure, was notified and approved in 2011. ${ }^{73}$ The aid, focused on the country's five most popular team sports (football, basketball, ice hockey, water polo, and handball), fell within the scope of EU rules but was compatible with them by virtue of Article 107(3)(c). The analytical structure follows that used in the cases dealing with stadium construction and the Commission cites Article 165 (though not on this occasion the Amsterdam Declaration on Sport).

It should be appreciated that simple invocation of Article 165 is not enough to shelter aid from Commission condemnation. In 2014 the Commission decided that three

${ }^{69}$ Commission Decision of 20 March 2013, Case COMP/ SA.35440, Germany - Multifunktionsarena der Stadt Jena.

${ }^{70}$ Commission Decision of 2 October 2013, Case COMP/ SA.36105, Germany - Fussballstadion Chemnitz.

${ }^{71}$ Commission Decision of 2 May 2013, Case COMP/ SA.33618, Sweden - Uppsala arena.

${ }^{72}$ Commission Decision of 9 April 2014, Case COMP/ SA.37342, United Kingdom - Regional stadia development in Northern Ireland.

${ }^{73}$ Commission Decision of 9 November 2011, Case COMP/ SA.31722, Hungary - Supporting the Hungarian sport sector via tax benefit scheme. 
companies that owned the German Nürburgring racetrack had received aid from the Land Rheinland-Pfalz in the period 2002-2012 that was incompatible with the internal market. ${ }^{74}$ The scheme fell outside the scope of permitted aid for the rescue and restructuring of ailing undertakings, as set out in Commission Guidelines which interpret Article 107(3)(c) TFEU in this context. ${ }^{75}$ In particular Germany failed to notify a restructuring plan and there was no evidence that aid granted was the minimum necessary. ${ }^{76}$ Germany's submissions included appeal to the common interest in the construction of sports facilities and, specifically, to Article 165 TFEU, 77 but the Commission simply ignored this in its findings. Presumably it did not disagree that Article 165 is relevant to assessment of aid for sports infrastructure, but Article 165 cannot help where what is at stake is inadequately planned restructuring of existing failing facilities.

The treatment of these several projects aimed at proving multi-purpose facilities, reflected now in Article 55 of the Block Exemption, clearly reveals a readiness to find a benefit in the common interest as a result of public funding, even where the main beneficiary is likely to be a professional football club. Heavy emphasis on transparency and non-discrimination in the operation of the stadiums is plain. In fact, this procedural

\footnotetext{
${ }^{74}$ Commission Decision of 1 October 2014, Case COMP/SA.31550 and Case COMP/SA.34890, Nurbürgring; Dec. 2016/151 (2016) OJ L34/1.

75 The current version is at (2014) OJ C249/1.

${ }^{76}$ Para. 219.

${ }^{77}$ Para. 83, citing Case COMP/SA.31722 Hungary - Supporting the Hungarian sport sector via tax benefit scheme.
} 
dimension is a feature of internal market law generally. ${ }^{78}$ And, of broader intellectual significance, these Decisions help to explore just how special sport truly is in the development of EU state aid law - this is very much the missing piece of the internal market jigsaw as far as EU sports law and policy is concerned.

We turn now to the second group of investigations, those dealing with advantages to particular clubs. These are particularly helpful in charting the limits of acceptance of sport's special nature.

\subsection{Tax and other advantages granted to clubs}

In contrast with the generally positive view granted by the Commission to the building of sports infrastructure, there is a more mixed view adopted in the examination of tax and other advantages granted directly to clubs. The most significant rulings are those of July 2016, in which the Commission took a broadly positive view of measures adopted in support of Dutch professional football clubs and a remorselessly negative view of measures addressed to leading Spanish football clubs, who are in consequence required to divest themselves of a number of advantages. The aim here is to discern the Commission's current view of what types of advantage states may grant sports clubs in Europe without falling fall of the restraint exercised by state aid law; and in particular whether the assessment is affected by recognition of the specificity of the sports sector.

\footnotetext{
${ }^{78}$ E.g. Case C-219/07, Nationale Raad van Dierenkwekers en Liefhebbers VZW, ECLI:EU:C:2008:353, [33-39]; Joined Cases C-186/11 and 209/11 Stanleybet International, ECLI:EU:C:2013:33 [47].
} 
The Commission sent a request for information in 2012 to all Member States. ${ }^{79}$ The letter mentions that the Commission had received complaints from citizens from different Member States indicating a number of state aid measures in favour of professional football clubs. At the same time, the Commission observed that very few measures have been notified to it, even though Article 108(3) TFEU requires notification by public authorities of plans to grant aid and imposes a "standstill" obligation on the grantor pending Commission investigation. Therefore, the Commission requested Member States to provide information on all measures supporting professional football clubs, in particular with regard to specific fiscal and social security regimes. ${ }^{80}$

\subsubsection{Aid to Dutch football clubs}

In 2013 the Commission opened an investigation into allegations that five municipalities in the Netherlands had granted aid to local professional football clubs (NEC Nijmegen, MVV Venlo, Willem II Tilburg, PSV Eindhoven and FC Den Bosch). ${ }^{81}$ None of the aid had been notified. This did not mean that the aid - if it be aid

\footnotetext{
${ }^{79}$ Commission, 'State aid to professional football clubs, Letter of the European Commission Competition DG to the Permanent Representation of the Member States’ COMP/C4/WP/ AH/ZZ/md - D*2012/98568, letter on file with the authors. See also Commission, 'State aid: Commission opens in-depth investigation into public funding of certain Spanish professional football clubs' Press release IP/13/1287, 18 December 2013.

${ }^{80}$ Ibid. at page 4.

${ }^{81}$ Commission Decision of 6 March 2013, Case COMP/SA.33584, The Netherlands - Alleged municipal aid to the professional Dutch football clubs Vitesse, NEC, Willem II, MVV, PSV and FC Den Bosch in 2008-2011.
} 
- is inevitably incompatible with EU law: the Commission must make that inquiry. It proceeded to do so.

It announced its findings on 4 July 2016. In one case, that concerning PSV Eindhoven, the Commission concluded after a careful evaluation that the deal, involving sale of the stadium to the municipality and a lease back to the club, was one into which a private investor would also have entered. ${ }^{82}$ This aligned with a decision already disposed of in 2013, in which the Commission decided that no State aid was involved where the municipality of Arnhem, to which the local club Vitesse owed money, had accepted a much reduced sum in settlement for fear that the club would become bankrupt were the full debt demanded. ${ }^{83}$ A private market creditor would have acted in the same way indeed several reportedly had.

The treatment of the other four clubs, NEC, MVV, Willem II and FC Den Bosch, was different, albeit a similar outcome was reached- that the grant of aid was not precluded by EU law. In each case support had been granted by local public authorities because the clubs were in financial difficulties. A private economic actor would not have acted in this way, so this was aid within the meaning of EU law. There is room to find aid compatible with EU law where it is used to rescue and restructure firms in difficulty, but the circumstances in which this is permitted are carefully confined in Commission's guidelines. These currently exist in a 2014 version, and are in essence a concrete application to the particular instance of restructuring of the 'gateway' found in Article

\footnotetext{
${ }^{82}$ Case COMP/ SA.41613, Aid to Dutch football club PSV; Dec. 2016/1849 (2016) OJ L 282/75.

${ }^{83}$ Case COMP/SA.33584 (n 81).
} 
107(3)(c), ${ }^{84}$ although in fact it was the earlier 2004 version which governed the cases at hand. The principal concern is, in short, that the aid granted shall be tied to a realistic plan for restructuring the undertaking's business and placing it on a viable footing and, moreover, the guidelines assert a "one time, last time” principle in order to reduce moral hazard, excessive risk-taking incentives and potential competitive distortions which flow from the grant of rescue aid. ${ }^{85}$

The Commission accepts that in principle football clubs may benefit in this way, as may firms in any other sector, but its preliminary assessment in 2013 found serious doubts whether the criteria were met. Thus, a full investigation was warranted. The Commission at the time mentioned Article 165 TFEU, but did not find it of assistance to the clubs in the particular circumstances that had arisen.

The 2016 final decisions, however, give a green light to the measures adopted in favour of the four clubs. The Commission approved the restructuring plan and found no violation of the "one time, last time" principle. Interestingly, Willem II does not cite Article 165 TFEU at all; ${ }^{86}$ the same is true of Den Bosch. ${ }^{87} M V V$, however, mentions it but only in brusquely denying that sport can benefit from the "cultural exception"

\footnotetext{
${ }^{84}$ Commission, 'Guidelines on State aid for rescuing and restructuring non-financial undertakings in difficulty’ (2014) OJ C249/01.

${ }^{85}$ Ibid. at para. 70.

${ }^{86}$ Case COMP/SA.40168, Willem II.

${ }^{87}$ Case COMP/SA.41614, Den Bosch.
} 
contained in Article 107(3)(d). ${ }^{88}$ NEC simply notes that "due account" is taken of Article 165 but makes no further use of it in the legal analysis. ${ }^{89}$ Here the crucial point is that sport is not special. Certainly the assessment is sensitive to the sporting context in which the restructuring occurs. A football club cannot change its core activity, but it can cut its costs. So, for example, the Commission notes how Willem II had sold players, paid reduced wages and retained a smaller squad than previously and that, doubtless in part as a consequence, had suffered relegation. ${ }^{90}$ But this is not to rely on Article 165 TFEU or, more generally, on the special features of sport to induce a more generous attitude to aid granted to ailing football clubs than to rescue aid more generally: it is only to provide a detailed application of the rules govering rescue aid in the particular economic context in which it arises, here football. The Commission, in short, was treating professional football like any other industry.

\subsubsection{Aid to Spanish football clubs}

Also in 2013 the Commission turned its attention to Spain and to some of the most famous and successful clubs in the history of the game of football. At stake are several issues. First, tax privileges alleged to have been enjoyed by Real Madrid, FC Barcelona, Athletic Club Bilbao, and CA Osasuna as a result of a special status held by those clubs

\footnotetext{
${ }^{88}$ Case COMP/SA.41612 (2016) OJ L 282/53 [45-46]: Art. 165 is also mentioned at [59] in connection with the restructured club's social function, but this is entirely tangential to the economic analysis of the restructuring plan.

${ }^{89}$ Case COMP/ SA.41617, NEC [68].

${ }^{90}$ Case COMP/ SA.40168, [48 and 51]. See also Case COMP/ SA.41617 [77-78 and 82].
} 
(alone) under the Spanish national sports act of $1990 .{ }^{91}$ Second, a transfer of land between the City authorities of Madrid and Real Madrid on terms alleged to be so favourable to the club that they amounted to state aid. ${ }^{92}$ Third, guarantees given by the Valencia regional government for loans to support Valencia C.F., Hércules C.F. and Elche C.F. (all three clubs in the region of Valencia, albeit in different cities) while the clubs were undergoing financial difficulties. ${ }^{93}$ The Commission expressed a preliminary view in 2013 that the measures in all three cases meet the criteria for state aid: they are financed by state resources, they provide advantages to selected professional clubs and they affect competition and trade between Member States. In that respect, the case of Hércules C.F. is interesting, for this relatively small Alicante-based club has been lingering in the second and third tiers of Spanish football for years.

Here the outcome was radically different from that reached in the Dutch cases. The Commission announced on 4 July 2016 that in the light of its three separate in-depth investigations it had reached the conclusion that public authorities in Spain had been

\footnotetext{
${ }^{91}$ Commission Decision of 18 December 2013, Case COMP/ SA.29769, Spain - State aid to certain Spanish professional sport clubs. These four clubs were allowed to continue being managed as members clubs (i.e. community owned), whereas all other professional football clubs in Spain were forced to transform into a special form of limited company (i.e. privately owned). This was enforced by the 1990 National Sports Act (Law 10/1990), for more on this see García, Palomar and Pérez 'Spain: Parochialism or Innovation?’ in Niemann, García and Grant (eds), The Transformation of European Football (MUP, 2010).

${ }^{92}$ Commission Decision of 18 December 2013, COMP/ Case SA.33754, Spain - Real Madrid CF.

${ }^{93}$ Commission Decision of 18 December 2013, COMP/ Case SA.36387, Spain - Alleged aid in favour of three Valencia football clubs.
} 
guilty of granting aid that is incompatible with the internal market to the named seven professional football clubs. They had as a result enjoyed an unfair advantage over their competitors, which now falls to be eliminated by recovery of the aid in compliance with EU law. The decision concerning Real Madrid, F.C. Barcelona, Athletic Club and C.A. Osasuna finds that the tax breaks enjoyed by the four clubs offer them a selective advantage of the type at which Article 107 is targeted. ${ }^{94}$ There was, moreover, liable to be an effect on inter-State trade and a distortion of competition. The decision concerning Real Madrid's transfer of land is founded on the conclusion that the transfer of land in question was not a deal that a private market operator would have chosen to enter into. ${ }^{95}$ The City of Madrid had, in short, over-paid. Once this crucial assessment had been arrived at, there was no escaping the classification of the transfer as aid within the meaning of Article 107, since the other definitional pre-requisites were clearly satisfied.

In both these two cases, concerning tax concessions and the transfer of land, the Commission in its 2013 documentation had explicitly cited Article 165 TFEU and the need to consider the specific nature of sport in the context of application of the state aid rules, "as sport fulfils educational, public health, social, cultural and recreational functions" but it noted too that "the economic importance of sport is growing constantly". ${ }^{96}$ It noted the absence of guidelines on the application of the State aid rules

\footnotetext{
${ }^{94}$ Case COMP/ SA.29769 (n 91).

${ }^{95}$ Case COMP/ SA.33754, Aid to Real Madrid.

${ }^{96}$ Case COMP/ SA.29769 (n 91), para. 30 of Commission letter, Case COMP/SA.33754, para. 38 of Commission letter.
} 
of the Treaty to commercial sport activities. It noted too that Spain does also not claim any public service mission of the professional sport clubs, which could be assessed under Article 106(2) TFEU. An assessment has therefore to be based on Article 107(3)(c) TFEU but the Commission in 2013 was plainly sceptical that one could identify an objective of common interest which could justify selective support to such powerful clubs in an intensely competitive market(s).

That scepticism is fully borne out in the decisions of 2016. In that pertaining to Real Madrid, F.C. Barcelona, Athletic Club Bilbao and C.A. Osasuna the Commission notes that the Spanish Liga Nacional de Fútbol Profesional had referred to Article 165 in claiming the rules in question were designed to promote the social responsibility of clubs and that any fiscal effects were merely indirect. ${ }^{97}$ However, neither Spain nor the recipient clubs themselves had claimed that any of the exceptions foreseen by Articles 107(2) and (3) were applicable. The Commission did not exclude that a connection might be made between the promotion of the European dimension in sport recognised by Article 165 and an objective of common interest within the meaning of Article 107(3)(c), but this could not help to justify a tax scheme that was not of general application but instead calculatedly selective. The Commission required only six paragraphs to conclude that the aid was not compatible with the internal market. ${ }^{98}$ It is now required that Spain shall end the concession and recover the wrongfully unpaid taxes. ${ }^{99}$

\footnotetext{
${ }^{97}$ Case COMP/ SA.29769 (n 91) [18].

${ }^{98}$ Ibid [84-89].

99 The decision has been challenged: Case T-679/16, Athletic Club v Commission.
} 
In the decision concerning the transfer of land in favour of Real Madrid the Commission concludes briskly that there is no route to finding the aid to be compatible with the internal market. Its reasoning requires just four short paragraphs, the core of which simply note that here too neither Spain nor the club has claimed that any of the exceptions contained in Article 107 apply. ${ }^{100}$ The club must therefore pay back a sum in excess of $€ 18$ million, which represents the benefit improperly conferred in violation of EU law. ${ }^{101}$ The club decided not to appeal the Commission decision and it recently paid the aid back to the Madrid city council, including the calculated interest, to a total of almost $€ 20.3$ million. ${ }^{102}$ Crucially, the Commission does not even mention Article 165 TFEU or Article 106(2) TFEU. Sport is in this case not special. As in the Dutch cases the aid was not notified, but in contrast to the Dutch cases there was no saving this grant of aid under EU law.

The decision concerning Valencia, Hércules and Elche contains a careful analysis of the nature of the support granted and the financial position of the clubs, and concludes that since a market investor would not have acted in this way, the matter constituted an aid within the meaning of Article 107 TFEU. ${ }^{103}$ In this case, the Commission in 2013 had linked assessment of whether aid may meet the criteria specified by Article 107(3)(c)

\footnotetext{
${ }^{100}$ Case COMP/ SA.33754 (n 95) [133-136].

${ }^{101}$ One can hardly avoid noting that the club regularly pays transfer fees far in excess of this amount: this is not an ailing football club.

${ }^{102}$ El Diario.es, 'El Real Madrid devuelve al Ayuntamiento de Carmena 20,3 millones de ayudas irregulares recibidas’ (4 November 2016) http://www.eldiario.es/politica/Real-Madrid-AyuntamientoCarmena-irregulares_0_576742899.html accessed 23 November 2016.
}

${ }^{103}$ Case COMP/ SA.36387, Aid to Valencia football clubs. 
TFEU as apt to facilitate the development of certain economic activities to Article 165's reference to the promotion of European sporting issues, while taking account of the specific nature of sport. But it remarked that the only recognisable objective seemed to be rescue and restructuring, and that several requirements for a green light under its Guidelines governing this type of aid were missing.

In its 2016 Decision on the Valencia trio of clubs, the Commission confirmed that the Guidelines on rescue and restructuring were not satisfied. In contrast to the Dutch cases, there was no managed plan for cutting costs and restoring the clubs to long-term financial viability. The Spanish Liga Nacional de Fútbol Profesional had argued for special treatment, citing Article 165, and had claimed to fulfil a public service, invoking Article 106(2). ${ }^{104}$ The Commission simply notes its obligation to take due account of Article 165, but does not integrate it any further into its legal analysis. ${ }^{105}$ Moreover it observes that professional football is supplied by market forces, and so there is no need for the State to place public service obligations on suppliers of such services; nor in any event had Spain done so. ${ }^{106}$ Article 106(2) therefore did not assist. Sport, in the circumstances, was not special. A total in excess of $€ 30$ million must be recovered from the clubs, most of it from Valencia C.F., and both Hércules and Valencia have lodged challenges to the Commission Decision before the General Court. ${ }^{107}$

\footnotetext{
${ }^{104}$ Ibid [48].

105 Ibid [101].

${ }^{106}$ Ibid [102].

${ }^{107}$ Cases T-766/16 and T-732/16 respectively, pending.
} 
The Spanish cases join a pool of pre-existing cases that are essentially straightforward as a matter of law. So for example the Commission, acting on a complaint lodged by a German ski producer, agreed in a decision of September 2012 that Slovenia had granted state aid in the form of an injection of capital to the company Elan, engaged in the production of winter sport equipment. ${ }^{108}$ The matter did not fall within the Commission’s carefully drawn guidelines designed to allow (but limit) aid for rescuing and restructuring firms in difficulty. ${ }^{109}$ Nor did the aid come even close to fitting the gateways envisaged by Article 107(3) TFEU. Slovenia was required to recover $€ 10$ million (plus interest) from the recipient. Crucially there was no sports-specific element to this case. This was naked state aid. This conclusion was also at the core of the Commission's condemnation of the practices uncovered in Spain.

However, if the lesson of the Spanish cases decided in 2016 is that sport is not special in law, a rather different story emerges when one thinks about how sport is special in politics. The Spanish cases were further complicated by the politics of the issue at stake, which seemed to have permeated the Commission's management of the dossiers. The Commission delayed four years from receipt of a complaint about the preferential tax treatment before opening this procedure and in fact in December 2013 the Ombudsman concluded that the Commission had failed to act in a timely manner and also that the Commission had failed to allay suspicions that the relevant Commissioner, Joaquín

\footnotetext{
${ }^{108}$ Commission Decision of 19 September 2012, Case COMP/ SA.26379, Slovenia - Measures in favour of ELAN d.o.o.

${ }^{109}$ Commission, 'Guidelines on State aid for rescuing and restructuring non-financial undertakings in difficulty’ (2014) OJ C249/1.
} 
Almunia a member and supporter of Athletic Club Bilbao, had a conflict of interest that caused the inaction. ${ }^{110}$ According to its own Code of Best Practice, the Commission should have decided within 12 months on whether it would act on the complaint. The Ombudsman was not persuaded by claims about the complexity of the matter and the lack of past practice as reason for delay, forcing the Commission to speed up its management of the case, which ended up with the decision to undertake an investigation. This clearly demonstrates that this is a sensitive issue. This is further emphasized by appreciation that since the aid was not notified to the Commission, it counted as unlawful aid and it was therefore open to competitor clubs (from Spain and beyond) to initiate legal proceedings before Spanish courts in order to prevent the recipients keeping their unlawful gains. That no club chose to do so provides a glimpse of the cartel that exists among football clubs, and highlights too just how important is the supervisory role of the Commission as the responsible public agency - even if, as in the Spanish cases, it showed little enthusiasm to act swiftly. There is here an echo of sorts of the discriminatory nationality rules in football, which were condemned by the Court of Justice in Bosman. ${ }^{111}$ They were not simply applied by UEFA because the Commission was not inclined to intervene: the Commission had in fact informally approved them despite their flagrant disrespect for EU law’s core values. ${ }^{112}$ It took a private party - a footballer - to go to court to crack open a cartel embracing UEFA, the

\footnotetext{
${ }^{110}$ European Ombudsman, 'State Aid and European football clubs? Summary of recommendation by the European Ombudsman following a complaint against the EU Commission’ (16 December 2013) http://www.ombudsman.europa.eu/en/cases/correspondence.faces/en/52874/html.bookmark accessed 23
}

November 2016.

111 Case C-415/93, Bosman (n 2)

112 This is recorded at paras. 126 and 136 of the ruling. 
clubs and the Commission itself. The incestuous politics of sport governance are truly special.

\section{Discussion: Legal assessment - the interaction of Article 165 TFEU and EU's} state aid rules

Our research has presented here an evolving, although relatively consistent, approach of the Commission to state aid and sport. Several conclusions can be extracted. Perhaps the first and more generic one is that Article 165 TFEU is having an impact on the Commission's reasoning. Article 165 TFEU is not explicitly horizontal in nature, but the Commission is clearly relying on it to develop its application and interpretation of the state aid rules. Thus, it is not a question of whether the special characteristics of sport are taken into account, but rather of the extent to which this is done. In fairness, this has been very much common practice of the Commission even before the entering into force of the Lisbon Treaty, ${ }^{113}$ but the new narrative is the extension of this approach to the state aid provisions and so to the public sector.

Second, the Commission has been consistently considering different types of measures as state aid, which should send a message to public authorities when considering their spending in matters of sport policy. Each case needs to be treated individually to ensure a justification under Article 107(3)(c) TFEU and, in this respect, one emerging trend is

\footnotetext{
${ }^{113}$ Weatherill, 'EU Sports Law: The Effect of the Lisbon Treaty' in Biondi, Eeckhout and Ripley (eds), EU Law After Lisbon (OUP, 2012) 403.
} 
that the stronger the link to tangible community/social benefits, the more likely are the arrangements to comply with the Commission's requirements.

Moving on from the more generic assessment, the Commission's readiness to treat the construction of arenas as an aspect of "State responsibility" is perhaps the most immediately striking aspect of these decisions. Given its explicit linkage to Article 165 TFEU and the Amsterdam Declaration on Sport this is where one may suppose that one finds an acceptance that sport is special - with direct consequences for the interpretation for funding granted to sport when controlled by EU state aid law. Basically, sport is special because of its social significance and therefore the state is responsible for providing infrastructure in this area of life to its citizens just as as it is, for example, responsible for building roads to improve transport or communication. This is certainly a bold claim in relation to the role of sport in society and its legal implications, and one that is doubtless immensely appealing to sports bodies and clubs as recipients of grants by public authorities.

Where does the claim about "responsibility" originate? This is not easy to answer. The Commission's explanations are not uniform, but the claim seems to originate in Ahoy. ${ }^{114}$ Copenhagen and Sweden/Uppsala offer no citation in support of the assertion that the project engages a State responsibility; France 2016 simply cites the decisions in Flanders, Sweden/Uppsala and the three German cases. ${ }^{115}$ So we see the Commission cross-referencing cases without providing a clear justification. Continuing the trail, the

\footnotetext{
${ }^{114}$ Decission 2009/713, Ahoy (n 30).

${ }^{115}$ Case COMP/ SA.35501, France Euro 2016, [269].
} 
Commission's explanations in the three cases on stadia in Germany, in Flanders and in Northern Ireland cite paragraph 67 of Ahoy in support of the claim that State responsibility is engaged. In Ahoy the Commission asserted:

(...) the investment in the Arena is intended to provide a venue at which activities will take place that are aimed at the general public. The provision of a sports venue of this type can be regarded as a matter for which the authorities are responsible to the general public, provided its multifunctional character is maintained. ${ }^{116}$

It should be noted that Ahoy was not the first case where the Commission hinted at the state responsibility with regard to the public funding of sports infrastructure. As described above, the Commission stated in relation to the funding of the Hannover stadium that a football stadium could be considered as being part of the typical responsibility of the public authority to the general public. ${ }^{117}$ However, Ahoy (like the Hannover football stadium case) was not a case of state aid! In that Decision the Commission placed the funding outwith the reach of the State aid rules because of the absence of (inter alia) a selective advantage. So, in relying on Ahoy to assert that State authorities are responsible to the general public when they provide a sports venue, the Commission has in the subsequent Decisions transposed the reasoning in Ahoy to support an analytically distinct finding - namely, that the financing provided is aid but that it is nonetheless compatible with the internal market.

\footnotetext{
${ }^{116}$ Decission 2009/713 (n 30), [47 and 61].

${ }^{117}$ SEC (2007) 935, (n 49).
} 
This is new in the sense that the Commission is plainly trying to identify a route through which to address sport's special concerns in the application of State aid law. However, State aid law is well accustomed to dealing with funding for infrastructure projects. Support for infrastructure projects will commonly escape the reach of the State aid rules in so far as it constitutes an aspect of general economic policy pursued by the State. However, once an element of selectivity infects the scheme, EU law comes into play. Improving a motorway network will not count as State aid - unless it is targeted on one particular region where a pool of particular undertakings will benefit. A State may choose a general tax regime which it intends to give an advantage to all firms on its territory when compared with firms based in other Member States, but once particular firms are picked out to enjoy the benefit, the line has been crossed: State aid is potentially involved, provided the other relevant criteria in Article 107(1) are satisfied. The scheme will need Commission approval to survive.

So, for example the Commission has published Guidelines on the application of State aid rules in relation to the rapid deployment of broadband networks under an assumption that in order to secure provision of widespread and affordable access to high-speed internet infrastructure and service some public funding is needed to complement private investment. ${ }^{118}$ Where access to the subsidised infrastructure is open to all sectors of the economy, State aid law has no say. However, it is different where a broadband network is provided in favour of predetermined companies that are not chosen according to general criteria applicable in the entire area for which the granting 
authority is responsible. It is the identification of a selective advantage that pushes an initiative of general economic policy over the line into the terrain of State aid and the consequent need to secure approval. Plenty of cases - decided by both Commission and Court - show careful examination of whether this line has been crossed, frequently in circumstances where public authorities are rather implausibly seeking to deny or even conceal the selective nature of their practices. ${ }^{119}$ Breadth of availability and nondiscriminatory access to the created benefits are particularly significant in keeping supervision in the name of state aid at bay.

One of the cases related to infrastructure is of high significance in understanding the rising tide of Commission intervention into aid granted in the sports sector, even though the matter itself did not concern sport. Mitteldeutsche Flughafen AG and Flughafen Leipzig-Halle GmbH v European Commission 120 involved judicial review of the Commission's investigation into the building of a southern runway at Leipzig-Halle airport. Public funding of air traffic control would be typical of the exercise of official powers and, absent selective treatment, would not fall within the scope of State aid law. However, the Court agreed that public financing of the construction or extension of airport infrastructure counted as an economic activity falling within the scope of the State aid rules. That such an infrastructure project might meet a clearly defined objective of general interest (in particular regional development) is part of the assessment of whether the aid is compatible with the internal market -it does not take

\footnotetext{
${ }^{119}$ See, e.g., Hancher, Ottervanger, and Slot, EU State Aids, $4^{\text {th }}$ ed. (Sweet and Maxwell 2012), 58-75.

${ }^{120}$ Joined Cases T-443/08 and T-455/08 and, on (unsuccessful) appeal, Case C-288/11 P, Mitteldeutsche Flughafen AG and Flughafen Leipzig-Halle GmbH v. European Commission, ECLI:EU:T:2011:17 and EU:C:2012:821 respectively.
} 
the matter outwith the reach of the rules. One may readily grasp the sensitivity associated with this extended understanding of the scope of EU state aid law by noting the protests advanced on appeal before the Court of Justice that the decision of the General Court caused an unconstitutional interference with the exclusive power of the Member States and a violation of the principle of subsidiarity. But such objections did not impress the Court. ${ }^{121}$

Van Rompuy and van Maren claim that it was primarily the case law of the EU courts that provided the Commission with propulsion to extend the reach of State aid control into sport. ${ }^{122}$ Although the Commission's first Decision relating to aid for sports infrastructure was made in late $2011^{123}$, they find that of particular significance in breaking the dam was the General Court judgment of 24 March 2011 in LeipzigHalle ${ }^{124}$ which, by adopting a relatively broad interpretation of the scope of Article 107 TFEU in such circumstances, provoked the Commission's approach to the public financing of sports infrastructure to become more muscular, even if Leipzig-Halle itself was not concerned with sport. This in turn quickly led to legislative codification of the Commission's decisional practice in Article 55 of Regulation 651/2014. The

\footnotetext{
${ }^{121}$ Case C-288/11P, Leipzig-Halle, [196 - 209].

${ }^{122}$ Van Rompuy and van Maren, 'EU Control of State aid to Professional Sport: Why Now? in Duval and Van Rompuy (eds), The Legacy of Bosman: Revisiting the Relationship between EU Law and Sport (TMC Asser Press 2016), Chapter 7.

${ }^{123}$ Commission Decision of 9 November 2011, Case COMP/ SA.31722, Hungary - Supporting the Hungarian sport sector via tax benefit scheme.

${ }^{124}$ Joined Cases T-443/08 and T-455/08 Mitteldeutsche Flughafen AG and Flughafen Leipzig-Halle GmbH v. European Commission.
} 
Commission's Decisions on multifunctional arenas follow the Leipzig-Halle model; so does Article 55 of Regulation 651/2014. To this extent sport is not special. But the acceptance that the State has a "responsibility" in the matter of providing sports arenas tends to improve the likelihood that aid will be found to be compatible with the internal market even where a selective advantage has unarguably been conferred. The nudge to the Commission supplied by Article 165 TFEU and the Amsterdam Declaration on Sport leads it to laud sport's educational, public health, social, cultural and recreational functions and to employ this as a basis for favourable assessment of public funding for sports arenas. However, this is generous. These Decisions, supplemented now by Article 55 of the Block Exemption Regulation 651/2014, make clear the requirement of wider and non-discriminatory community access to the publicly funded arenas as a condition of finding the aid compatible with EU law, but the reality remains that the principal beneficiaries will (often) tend to be rich and powerful professional football clubs. This is clear from the list of cases analysed. Their commercial motivation is much harder to align with sport's educational, public health, social, cultural and recreational functions. In fact, one may argue that the Commission, by taking a very broad view of sport's virtues, is adopting an unduly benevolent view of professional sport, which is mainly (though not exclusively) pursued for profit-making.

Strategically, however, this is the route for professional sport to seek to exploit in order to carve out special protection for its interests in the application of EU state aid law. The notion of State responsibility to support sport offers a window to generous treatment of public funding for sporting activities. The question is, how far will this stretch, and how far should it stretch? 
The Dutch and Spanish cases, and to some extent the 2001 Decision on French football clubs' academies, ${ }^{125}$ help to show the limits. In the infrastructure cases, and even in the youth academies case, there is at least a tangible outcome that can be linked to the social nature of sport and its links to communities. Stadia may be used for different purposes. The Commission may well be forced to further develop its thinking on sport infrastructure by applying criteria on the use of the stadia for clear and measurable socially useful purposes. In this respect it is necessary to note the clear focus on the virtues of grassroots sport that Commission, Council and Parliament have decided to take in their early implementation of the nascent EU Sport Policy. ${ }^{126}$

All this is certainly different from providing tax relief and other advantages to single clubs, where the link to tangible community/social benefits is rather tenuous once clubs have been considered as undertakings. Tax benefits and similar measures also provide a more direct advantage to the undertaking in the case, with a further potential to distort competition in the market. Thus, whereas one could consider the Commission rather generous in agreeing that the state is responsible to build sporting facilities, there are instruments available to ensure these practices achieve their stated objective, although this will of course require assertive policing by the competition authorities. Where aid is granted to clubs to reduce their operating costs, a quite different approach is merited,

\footnotetext{
${ }^{125}$ Commission, 'Commission does not object to subsidies for French professional sport clubs' Press release IP/01/599, 25 April 2001.

${ }^{126}$ E.g. Commission Comunication, Developing the European Dimension in Sport (n 52); Resolution of the Council and of the Representatives of the Governments of the Member States, meeting within the Council, on a European Union Work Plan for Sport for 2011-2014, (2011) OJ C162/1.
} 
and it is plainbly visible in - most of all - the Dutch and Spanish decisions of July 2016. These reveal a basically orthodox approach to assessment of aid devoted to restructuring and rescue: one that has sport as the background, but one which would be familiar to those engaged in restructuring aid across the economy more generally. Such aid is certainly not ruled out - as the Dutch cases prove - but it is confined to the circumstances recognised by the Commission's Guidelines, as a concrete application of the Article 107(3)(c) 'gateway', and the types of practices uncovered in Spain are not acceptable. Sport is not in this matter special, and this is amply demonstrated by the Commission's lack of detailed concern for Article 165 TFEU in the July 2016 Decisions.

\section{Conclusion}

The law of the internal market came relatively late to sport. Walrave ${ }^{127}$ was the first ruling of the Court of Justice which applied EU law to sport, but it was the Bosman ruling in 1995 that was the trigger for an explosion of interest and litigation in the matter. ${ }^{128}$ Bosman showed that the Court would not yield absolute autonomy to sports governing bodies where their rules conflicted with the assumptions of EU free movement law, but nevertheless the Court in Bosman left some interpretative room in EU law for the expression of sport's special features. ${ }^{129}$ Meca-Medina is the landmark case that performed a similar job for the shaping of EU competition law in the

\footnotetext{
${ }^{127}$ Case C-36/74 Walrave (n 1).

${ }^{128}$ Case C-415/93 Bosman (n 2).

${ }^{129}$ Ibid see especially para. 106 of the judgment.
} 
supervision of sporting practices with economic effects. ${ }^{130}$ Article 165 TFEU captures this trend in its direction that EU law shall take account of "the specific nature of sport". And now state aid law too joins the party by bringing the role of public authorities in sport's economic model into focus. These are transformative times: the determination of the extent to which sport is truly 'special' now falls to be decided in the context of the intervention of public authorities.

The development of state aid law applied to sport over the last ten years is best understood as a process of testing just how rigorous shall be this control exercised over aid that tends to "disrupt fair competition”. Legally this is influenced by the need to inquire into whether the insertion of Article 165 into the TFEU with effect from 2009 has changed the rules of the game: in particular, does appeal to the "specific nature" of sport generate any more lenient understanding of the control exercised by state aid law over subsidies to sports clubs.

The evolving practice reveals that the grant of support by public authorities to sporting activities is reviewed in the light of both Articles 107-109 TFEU and Article 165 TFEU. That means that sensitivity to sport's character is embraced by the Commission. This follows Bosman and Meca-Medina. However, a detailed and case-by-case assessment is required: this is no general amnesty for aid granted simply because the recipient wears the clothes of sport. This too follows Bosman and Meca-Medina. It is so far plain that the perceived social value of infrastructure is treated as justifying a far more generous view of public support for sport than is extended to more narrowly commercial benefits

\footnotetext{
${ }^{130}$ Case C-519/04 Meca-Medina (n 5) See especially [43-45].
} 
offered by public authorities to particular (often ailing) football clubs. This begins to illuminate an understanding of the possibilities but also the limits under EU law of aid granted by public authorities to the sports sector. Sport deserves to be treated as a special case, distinct from other areas of economic activity, but not to the full extent claimed by some public authorities and sporting bodies. 
Geolocation information

European Union, Europe 